\title{
ON THE NATURE OF THE GOVERNING SYSTEM OF THE QIN EMPIRE IN ANCIENT CHINA ${ }^{1}$
}

\author{
Tarmo Kulmar
}

\begin{abstract}
The article demonstrates that the Inca Empire was not the first early totalitarian state of its kind; we can find an even more obvious precedent for an early totalitarian state from ancient China, namely in the Qin Empire (221-207 BC). The legalist political theory, which was aimed at establishing the ruler's absolute control over society and consolidating the central authority, is the first theory justifying totalitarian power known in world history. The authors of the Fajia (Legalism) theory (Guan Zhong, Shang Yang, Han Feizi) made a number of more or less successful attempts to implement a system of government based on it. The analysis of Sima Qian's chronicle and the main arguments of the studies based on it show that, in view of the existing knowledge of the foundation and collapse of the Qin Empire, the structure of its governmental system, economic measures, ordering of society, legal system, religious and ideological policy, as well as its armed forces and foreign policy, the Qin Empire can certainly be identified as one of the earliest totalitarian superpowers in world history.
\end{abstract}

Keywords: ancient China, earliest totalitarianism, ideology, legalism, Qin Empire, society, state power

\section{INTRODUCTION}

I have made an earlier attempt to posit the concept of the so-called early totalitarian state and outline its main characteristics. The aim of that research was to demonstrate, based on historical records, that the Peruvian Inca State set a precedent for a special kind of governing system whose characteristics point, to a greater or lesser extent, to early totalitarianism (see Kulmar 2003: 25-39).

The aim of the present article is to demonstrate that the Inca State was not the first or only of its kind, and that we may find an even more obvious precedent for an early totalitarian state from ancient Chinese history, namely in the Qin Empire. I am not the first to suggest the idea. Legalism has been explicitly identified as a totalitarian philosophy by Leonid Vasilyev, a Russian sinologist (Vasilyev 1989: 108). 
Historical material from the period has been preserved for posterity by Sima Qian², an ancient Chinese historian, in Chapter 6, Qin Shihuang benji (An Outline of the Deeds of the First Emperor of the Qin Dynasty), of his grand work Shiji (Historical Notes). Sima Qian was the son of Sima Tang, a historiographer of Emperor Wu Di of the Han dynasty (born ca. 135 BC). He started his chronicle in $104 \mathrm{BC}$, and completed it three years later. In $99 \mathrm{BC}$, he was convicted of insulting the majesty for writing the truth about a favourite of the emperor, and castrated as a punishment. Sima Qian died a few years later (Kryukov 1972: 12ff.). Chapter 6 of Sima Qian's chronicle is unique as a source of Qin's history. It is considered accurate and reliable because of its reliance on an extremely varied basis of sources; unfortunately, a large number of these original sources are not extant (Vyatkin 1972: 92-95).

Significant advances in studying ancient Chinese philosophy and statehood have been made by the Russian school of sinology headed by N. Konrad, L. Menshikov, M. Kryukov, R. Vyatkin, V. Taskin, L. Perelomov, and L. Vasilyev. Hence it is only natural for me to use the pioneering studies by L. Perelomov, M. Kryukov, and L. Vasilyev for the evaluation of legalist philosophy and the political practice of the Qin state. To avoid the danger of one-sidedness, I have referred to an article by S. Durrant (1987), which contains references to the major representatives of the American school of sinology.

\section{DEVELOPMENT OF THE LEGALIST POLITICAL THEORY IN ANCIENT CHINA AND THE EARLIEST ATTEMPTS AT IMPLEMENTATION}

Legalism (Fajia) is one of the oldest Chinese philosophical systems; it declares the priority of the state over the individual, subjecting human life and actions to the interests of the state.

The teaching of Fajia was founded and first implemented by Guanzi or Guan Zhong, a dignitary from Qi, who lived in the 7th century BC (died in 645 BC). His book Guan-zi ([Writings of] Master Guan), containing his teachings on the basics of political theory and economics, was committed to writing in the 5th century BC. The kingdom of Qi, one of the seven states of the so-called Warring States Period of China, had a well-developed economy and commerce. It featured extensive economic differentiation, high taxation and, as a result, a great number of destitute peasants, who fled illegally from the countryside to towns. The main idea of Guan Zhong was "rich state, strong army". In his view the foundation for a rich state was agriculture, and the characteristic feature of a strong state was its army. Guan Zhong divided social hierarchy according 
to relative importance into officials, peasants, craftsmen, and merchants. In addition to that, he tried to replace the traditional communal system with a vertical administrative system and to group people - for a more effective control and tax management - into five-family units. Guan Zhong stated that a ruler must be a strong personality who dares to take major economical and political steps for the consolidation of the state. He was the first thinker in Chinese history to formulate the concept of government based on laws. The law is supreme; even the ruler has to observe it. Punishment is a moral factor. People have to fear the power, as they fear a serious disease. Agriculture is a source of prosperity. If people have enough to eat, the well-equipped army is ready for battle and no-one dares to attack the state. Commerce, however, interferes with agriculture. It should be curtailed or even banned. Hence Guan Zhong favoured autarchic economy.

By the order of the ruler, Guan Zhong's laws were inscribed on ritualistic bronze vessels of Qi. Yet Guan Zhong made the mistake of requiring social restructuring and, as a result, lost the support of nobility while tribal legacy was still too strong to resist (Perelomov 1981: 41-44).

In the 6th century, the tenets of Fajia were practiced by $\mathbf{Z i ~ C h a n , ~ w h o ~ a s ~}$ adviser to Prince Zheng promulgated a number of laws in 536 BC.

Zi Chan devoted much attention to amelioration and opening of wastelands for cultivation, and made an end to periodic redistributions of land. He also divided the populace into 5 -household units bound together by the frankpledge or joint liability system (for the first time in China). Zi Chan established a new administrative division headed by the king's officials, aiming to transfer the community members from the hereditary aristocracy's sphere of influence to direct subordination to the ruler and thus consolidate the king's (wang) personal power. For the same purpose, uniforms were provided for officials to distinguish them from hereditary aristocracy, and differences between town and country were underlined to emphasise the importance of the capital. Finding that aristocratic families posed a danger to the ruler, he suggested leaning on the middle and lower strata of society. In addition to that, Zi Chan recognised a community member's right to land ownership, which did not please the nobility.

Zi Chan was a state official, not a theoretician. This may have been the reason why he, knowing the circumstances, was more flexible in his reforms than Guan Zhong, not pressing them to completion (Perelomov 1981: 45-50).

The main theoretician of legalist philosophy, who managed to implement his ideas, was Shang Yang (390-338 BC). Coming from an impoverished aristocratic family of the state of Wei, he became adviser to Xiao Gong, the ruler of Qin, and was able to persuade the wang to carry out the political programme 
contained in his work Shang jun shu (see Shang Yang 1993: 139-240; Durrant 1987: 497-498).

Economy must be geared to the consolidation of the state. Shang Yang paid particular attention to agriculture in an attempt to stop the peasants' pauperisation and running away from villages. Virgin lands had to be cleared and cultivated as redistribution of land was unthinkable; new settlers were given benefits. At the same time, he prohibited giving shelter to escaped villagers. The sale and purchase of land were legalised to undermine the economic power of hereditary aristocracy. In this way, Shang Yang was able to muster the support of wealthy community members in the struggle against aristocracy. He established the official sale of state offices and ranks of honour, because of its lucrativeness for the state, creating a new privileged stratum of society.

Like Guang Zhong, he found that the number of merchants should be limited. Commerce should be a state monopoly and the state should regulate market prices. On the whole, the ruler's economic function should be to exercise state control over economy (Shang Yang 1993: 139-240; Vasilyev 1989: 108-121).

Political governance and society. The state had to be uniform, undivided, orderly and monarchist (this was also the view of Confucius). But the difference of Shang Yang consisted in the following. A humane ruler, according to him, was unrealistic, for that would give rise to corruption. It was necessary to rely on the foundation of the law. Absolute obedience to the ruler's word was essential. Well-functioning state machinery guaranteed the enforcement of the laws. Laws were to be made by the ruler. The ruler was sovereign over the law and did not answer to anyone. The law was a buttress of the monarchy. At the same time, the law had to be well in accordance with the customs of the people, because it was habitual for people to follow customs. People had to believe in the reliability and infallibility of the political power, and for this purpose explanatory work was needed. The power of the aristocracy had to be curtailed, and aristocracy had to be subjected to the ruler. Shang Yang also provided a definition of the people, "People ( $\mathrm{min}$ ) is the unity of the poor and the wealthy, for the former shall become the latter and vice versa". People had no political rights. Distrust and fear of one another needed to be generated (especially among the upper classes) to avoid any threat to the ruler from below. The might of the state consisted in its oneness and unity. Shang Yang's idea was "weak people, strong state". It was necessary to build a new type of state machinery. Only a weak bureaucracy could become a servant to the ruler, whereas a strong bureaucracy would get out of hand.

Conception of man. A perfect man could not have any of the so-called parasitic traits, which derived from Confucian values, and in Shang Yang's opinion the depravities were: singing of lampoons, making music, charity, veneration 
of ancient customs, respecting one's parents, brotherly love, selflessness, philanthropy, rhetoric, witticisms. All these would lead a man away from serving the state, Shang Yang meant.

Law and order. Offences and punishments needed to be differentiated. A great guilt deserved a severe punishment. Shang Yang thought it necessary, in order to secure obedience and inspire fear, to introduce the system of 'neighbour responsibility': a father will be responsible for a son, a wife for a husband, etc. Joint responsibility in the army made an end to desertion, for if anyone deserted, the whole squad would face capital punishment. Shang Yang also employed prophylactic disciplining of soldiers by beating the soles of their feet with a stick, in order to arouse fear of the punishment waiting for them in case of an offence (Shang Yang 1993: 139-240; Perelomov 1981: 115-130; Vasilyev 1989: 108-121).

Views on foreign policy. Confucius taught that ethical virtues were characteristic only of the Chinese. Shang Yang agreed that the Chinese were undoubtedly superior to other peoples, but the approach had to be pragmatic, based on the needs and profit of the land and the ruler. Warfare, like agriculture, was a source of income and one of the virtues. Wars of conquest were inevitable (Shang Yang 1993: 139-240; Perelomov 1981: 131-155; Vasilyev 1989: 108-121).

At Shang Yang's suggestion, most of the above ideas were enacted in $356 \mathrm{BC}$ as state laws. In $350 \mathrm{BC}$, he imposed a new administrative division and regulated the tax system. The chronicle of Sima Qian provides a number of examples of that. In villages, groups of five and ten households were formed, requiring mutual surveillance and joint responsibility inside the group. Anyone who failed to report a crime was to be cut in half; anyone who reported a crime was rewarded; anyone who hid a criminal would face a traitor's punishment. If there were more than two males of working age in a family and one of them did not marry, their tax was doubled. Anyone who worked hard and produced much was exempted from the public labour conscription, e.g., the construction works. Military services to one's country were rewarded with a rank of honour. The owner of a rank was entitled to property.

A general who fought with another general for self-interest (for example, as an initiator of a civil war), was punished according to the dangerousness of his motive.

Naturally, hereditary aristocracy offered great resistance to the new system of governance, but their resistance was ruthlessly suppressed (Shang Yang 1993: 139-240; Perelomov 1981: 156-157; Durrant 1987: 498).

So Shang Yang held that economy, politics, and social life had to be entirely subjected to the state machinery. He thereby laid a foundation to the bureaucratic state of China, which in a milder form persisted throughout China's 
subsequent history. By its nature, Shang Yang's teaching was clearly antiConfucianist and totalitarian. At the same time, the strengthening of the state of Qin demonstrated the vitality of Shang Yang's teaching, and it was difficult for Confucianists to fight against it.

The final form to the legalist teaching was given by Han Feizi (280-233 BC). Coming from an aristocratic family of the Han state, Han Feizi had learned of the teaching of Shang Yang and his actions in the kingdom of Qin. As Shang Yang's new bureaucracy corrupted and abuse of office started in Qin, Han Feizi paid special attention to the issues of developing bureaucracy, and to the psychology of an official. He maintained that a wise ruler had to know how to conceal his thoughts and motives from his officials, be state-wise, flexible, and to modify the laws according to the need. Han Feizi's main concern was with the tactics of government (Vasilyev 1989: 211-215).

Special interest in Han Feizi's teaching was taken in the state of Qin, where legalism served as the official system of government. The wang of Qin, later emperor ( $d i$ ) of China, Shi Huangdi, invited him to become his adviser, but, as a result of the intrigues of Shi Huangdi's later all-powerful minister Li Si, Han Feizi was arrested and then poisoned in jail (Sima Qian 1975: 53-58; Perelomov 1981: 166-169).

\section{THE QIN EMPIRE AS THE FIRST CENTRALISED CHINESE STATE (221-207 BC)}

\subsection{Historical background: The rise and fall of the empire}

In 246 BC, a 13-year-old Ying Zheng ascended the throne of Qin. As Qin's ruler, he set about the unification of the whole China. In 234 BC, Ying Zheng invited Li Si to become his Prime Minister. One after another, all the other states of China were subjected: Han in 230 BC, Zhao in 228 BC, Wei in 225 BC, Chu in 223 BC, Yan in 222 BC, and Qi in 221 BC. By April 221 BC, all the six states had been incorporated into Qin, making it the first Chinese empire. The surrendered armies were disarmed, all weapons were gathered to Qin's capital Xianyang, where they were melted down and cast as bells and statues. ${ }^{3}$ Ying Zhen assumed the imperial title of Shi Huangdi ('First Sovereign Emperor') (Sima Qian 1975: 62-63; Perelomov 1981: 191ff.; Perelomov 1962: 34-38).

The emperor died in $210 \mathrm{BC}$, at the age of fifty. ${ }^{4}$ The letter to the heir to the throne, Fu Su, with the dying emperor's last arrangements, was never sent out. Fearing the outbreak of unrest, $\mathrm{Li} \mathrm{Si}$ concealed the fact of the emperor's death. The corpse was put in the royal carriage and the procession headed for 
the capital as if the emperor were still alive. ${ }^{5}$ Only $\mathrm{Li} \mathrm{Si}$, another son of the emperor, Hu Hai, and some of the more trusted officials knew the truth. With the connivance of $\mathrm{Li} \mathrm{Si}$, the 21-year-old $\mathrm{Hu}$ Hai was proclaimed emperor, and he assumed the title of Er Shi Huangdi ('Second Sovereign Emperor'), while the legal heir to the throne, $\mathrm{Fu} \mathrm{Su}$, was sent the proposal of the "death of honour", i.e., he was forced to commit suicide. Er Shi had higher officials executed and his own brothers murdered. Even the "architect" of the empire, Li Si, soon found his death. As riots became more and more frequent, the emperor had to hide in the secret chamber of his palace and to take counsel only from his new adviser Zhao Gai. In July 207 BC, the adviser staged a coup d'état, and Er Shi was forced to commit suicide. At the end of the same year, the last emperor of the Qin dynasty was killed. This marked the end of the Qin Empire that had lasted for 14 years. The civil war that broke out in the aftermath did not end until 202 BC with the creation of the Han Empire by the founder of the Han dynasty, Liu Bang (Sima Qian 1975: 86-98; Perelomov 1962: 182-208; Perelomov 1981: 191-204).

Hence, the Qin Empire came into being as a result of military conquests. Like most totalitarian states, it lasted for a relatively short period of time and disintegrated as a result of escalating interior conflicts.

\subsection{Administration: Building up the state machinery}

Following the advice of $\mathrm{Li} \mathrm{Si}$, centrally controlled organs of state were established, such as departments of war, law courts, finance, the imperial court, manners, and life guard, as well as the prosecutor's office. Li Si as Minister of the Imperial Palace (shaofu) had immense powers. He commanded the irrigation systems, commerce of salt and iron, handicraft for the imperial palace, and the arsenal; he was keeper of the state seal, top religious official and head of the emperor's life guard. Enforcement of laws and court decisions was supervised by the State Audit Office. Administratively, the empire was divided into 36 provinces, which were made up of commanderies, which in turn were divided into counties. Each province and each commandery had its governor, offices, and representatives of all the ministries.

$\mathrm{Li}$ Si created a standardised system of coinage, weights and measures. Copper, silver and gold coins of fixed weight and form began to be minted as early as $221 \mathrm{BC}$. The same year saw the creation of a standardised writing system, which played a crucial role in the building of the empire (Sima Qian 1975: 64-65; Perelomov 1962: 44-46; Perelomov 1981: 191-204). 
Hence, in terms of bureaucracy, the Qin Empire possessed an efficient state machinery by which the ruling elite, isolated from the people, wielded rigidly centralised power, seeking to exercise absolute control over all the facets of life in the empire.

\subsection{Economy and infrastructure}

In economy, the main emphasis was on promoting agriculture. Village communities had been replaced by one-family households. Compared to earlier times, the situation of agricultural community members somewhat improved, as the taxation of peasants became standardised and was brought under state control. Hereditary aristocracy was no longer able to require excessive taxes from the peasants. Poll tax was imposed in $221 \mathrm{BC}$, land tax on farms in $216 \mathrm{BC}$. Commerce became secondary; merchants and owners of big workshops were supported, but petty tradesmen fell lower than free peasants in the social hierarchy; by such means peasants were shown that they had nothing good to expect, should they escape from the village. For example, petty tradesmen were the first to be conscripted for public works; then came persons of suspicious origin, and, finally, peasants. Wealthier merchants were able to buy their freedom; they could even purchase ranks of honour.

The state required regular public labour service in many fields: the construction of the Great Wall, fortresses, roads, border fortifications and imperial palaces, land and water transport, building of irrigation systems, opening virgin lands for agriculture. Officials and those who could buy their freedom were exempted from labour conscription. The unification of the country through a good network of roads facilitated the settling of hinterlands and cultivating of wastelands, which in turn promoted state economy. The emperor himself travelled extensively and inspected local observance of laws (Sima Qian 1975: 66-71; Perelomov 1962: 111-117; Perelomov 1981: 191-204; Kryukov et al. 1983: 28-29).

So, in the state of Qin, there were prevailing tendencies towards the domination of the state property (belonging to the emperor) over the private property of the old aristocracy, towards autarchic economy, the planning of production and consumption. The other salient features of the Qin economy were general labour conscription, arbitrarily imposed market relations, and state coercion in the execution of herculean projects. 


\subsection{Social life and measures}

In $221 \mathrm{BC}$, the emperor ordered 120,000 aristocratic and merchant families taken as hostages to the capital, Xianyang, to prevent the subject states from restoring their armies. By repressing the old aristocracy, the emperor supported the new bureaucracy and officers of Qin origin. The army's command personnel were appointed only from the ranks of the latter. Qin's garrisons were planted in all the provinces. In $220 \mathrm{BC}$, Shi Huangdi promoted all officers of Qin origin to a higher rank.

An individual could choose his occupation only horizontally, within his social stratum, whereas the permission for vertical mobility in the social hierarchy was the sovereign's prerogative to grant or deny. The aim of the state was to make the officials obedient to the emperor by way of benefits and punishments; this was also the aim of the system of buying and selling ranks. Whole communities were forcibly resettled from parts of the empire to wastelands and borderlands. The resettled lived in paramilitary settlements under strict regime, but were exempted from public duties, except for military service. Villagers and petty tradesmen were forbidden to travel or move anywhere without special permission from the state.

The active home and foreign policy was mostly financed from the work of peasants, and as the labour and military obligations increased, many people fled to the swamps and mountains, making up a large asocial stratum that became one of the factors contributing to the triumph of the Han dynasty in the civil war of the empire's final years (Sima Qian 1975: 66-77; Perelomov 1962: 111-117; Perelomov 1981: 191-204; Kryukov et al. 1983: 36ff.).

So the state of Qin used its control mechanisms to regulate the structure of society, to limit the freedom of movement and the freedom of choosing occupation; some strata of society were preferred to the others; some groups of the population were deported and assimilated.

\subsection{Law and order}

Since $221 \mathrm{BC}$, customs and laws began to be standardised and a written code of law was established as a basis for the administration of justice. All the provinces had judges, executives and inspectors appointed from the capital. Villagers by groups of five or ten households were imposed joint liability (frankpledge), which involved keeping watch on one another and joint punishment for the whole unit if any of its members offended the law. Emperor Er Shi Huangdi extended the system of group responsibility and watching each other on the 
aristocracy and top officials, in order to unmask his enemies and, for example, his brothers as power rivals. In this way very many innocent people suffered; their property was confiscated and they were sentenced to state slavery or executed. In interpreting the laws the tendency was to forbid everything that was not explicitly permitted.

Capital punishment was mostly administered in case of subversive acts, but these were many. Only the higher nobility and officials could expect the so-called death of honour, for which purpose the emperor had a sword sent to them. In the case of high treason the offender was executed, and sometimes the families of his parents and of his wife were also killed. Likewise, the punishment for owning forbidden literature or criticising the authorities was execution of the whole family. Among the legal ways of execution were tearing in four, cutting in half or in pieces, beheading and impaling the head, slow strangulation, burying alive, boiling alive, and breaking the bones. Fear of these terrible punishments was so great, however, that the kind of crimes and executions were relatively rare. Much more frequent were the punishments of "hard labour", which provided the state with cheap manpower: sentencing to forced labour or state slavery, conscripting to work on the construction of the Great Wall, frontier fortifications, palaces or temples. Not infrequently a supplementary punishment of physical mutilation was meted out: emasculation, hamstringing, cutting off the nose or the ears, blinding, and branding. By far the most common, however, was corporal punishment, especially beating the soles of feet with a cane, which was sometimes used in the army for the prophylactic purpose of preventing disciplinary violations (Sima Qian 1975: 75-81; Perelomov 1962: 132-140; Perelomov 1981: 191-204; Kryukov et al. 1983: 344ff.).

The legislation of Qin enforced cruel punishments, above all, for crimes against the state; joint responsibility dominated over personal; the interpretation of laws followed the principle, "What is not permitted is forbidden". The observance of laws was monitored by the large supervisory and coercive machinery.

\subsection{Ideology: Measures in the sphere of religion}

Li Si himself supervised the observance of customs and worship; the high priest of the empire was subordinate to him. In $213 \mathrm{BC}$, the destruction of Confucianist literature, which was considered dangerous to the legalist state and conducive to free thinking, was started. In $212 \mathrm{BC}$, regular prophylactic interrogations of state officials began. The law required that all those who disseminated the teaching of Confucius by word of mouth - those "who say it was better in the old 
days" - be put to death. The official who failed to report a crime suffered the same punishment himself. More than 460 Confucianist scholars were buried alive; the rest were exiled. About the same time, the destruction of forbidden Confucianist literature started. A black list was compiled. Those who did not burn their Confucianist books in 13 days were chained and sent to the construction of the Great Wall for a period of four years. Incidentally, the forbidden literature of only the private collections was to be destroyed; in state libraries, a number of copies were preserved and later moved into the so-called special collections. Works of a more applied nature - texts on medicine, pharmacy, divination or agriculture - were not destroyed. Records of Qin's history were preserved, but the chronicles of other states were largely destroyed. By censoring history, which had been done already by Shang Yang, Li Si intended to cut the roots of people's rebelliousness. So Confucianism was banned, whereas the ancient Chinese cult of the nature and heaven was permitted and even favoured as a religion. The superiority of the Chinese was proclaimed at the state level and applied in ruling the subject peoples.

In the sphere of state ideology, $\mathrm{Li} \mathrm{Si}$ introduced the cult of an all-powerful and divine emperor. People were constantly told that the emperor was a wise and prudent ruler, who worked from early morning till late night for the good of his people; all men and women were law-abiding, and everyone fulfilled their duties; there was peace and order in the empire. This is the text of many inscriptions on stone. The emperor's capacity for work was really huge; he is reported to have read 30 kilogrammes of documents a day. During his last years, Qin Shi Huangdi grew paranoid. He never stopped or lived anywhere for long, nor did he inform even his closest associates of his leaving. The emperor had 270 palaces always ready to welcome him within the radius $200 \mathrm{li}^{6}$ from the capital. His whereabouts were known by few; anyone who knew and prated was put to death. Despite repressions and ideological purges, intellectual opposition grew stronger (Sima Qian 1975: 66, 77, 79-81; Perelomov 1962: 153-166; Perelomov 1981: 191-204; Kryukov et al. 1983: 335; Durrant 1987: 499).

Accordingly, legalist political theory and the animist cult of the heaven were raised to the status of state religion. Confucianism as a religion and philosophy like all the other philosophies was banned. To this were added the mythologised emperor cult, the doctrine of ethnocentrism, and purposefully directed educational and cultural policy together with the censoring of information and historiography for the purpose of uniforming thought. 


\subsection{Armed forces and aggressive foreign policy}

In $215 \mathrm{BC}$, as the rebelliousness of the old aristocracy persisted, the emperor ordered the demolition of all defence structures and domestic fortifications of the six subject states, except for the northern frontier, where the construction of the Great Wall had started. Men were recruited to the armed forces beginning from the age of twenty three. Military service consisted of three parts: first, one month of service in the province; then, a year of service in the regular army, and finally, a year of service in the frontier defence. It was possible to buy one's exemption from the military service, which cost 2000 coins; exemption from the frontier defence cost 300 coins. The price was high, for the empire needed soldiers; especially the rural poor were always required to complete military service. But even the aristocracy had to serve in the army if they wanted to earn ranks.

Shi Huangdi and Er Shi Huangdi waged a number of wars of conquest and defence on the northern and southern borders of China. To thwart invasion from the north, in $215 \mathrm{BC}$, the construction of the Great Wall was started, which went on for centuries. Hundreds of thousands of people perished in the process even during the Qin Empire (Sima Qian 1975: 74-75; Perelomov 1962: 166-174; Perelomov 1981: 191-204; Kryukov et al. 1983: 105-110).

The Qin Empire built a huge regular army as it sought political hegemony over neighbouring territories and systematically implemented an aggressive foreign policy.

\section{CONCLUSIONS}

The legalist political theory, which was aimed at establishing the ruler's absolute control over society and consolidating the central authority, is the first theory known in world history that justifies totalitarian power.

The authors of the Fajia theory made a number of more or less successful attempts to implement a system of government based on it. By far the most successful attempt was that of $\mathrm{Li} \mathrm{Si}$, the minister (vizier) to the emperor Qin Shi Huang.

The analysis of Sima Qian's chronicle and the main arguments of the studies based on it show that in view of the existing knowledge of the foundation and collapse of the Qin Empire, of the structure of its system of government, economic measures, ordering of society, legal system, policy of religion and ideology as well as its armed forces and foreign policy, can certainly be identified as one of the earliest totalitarian superpowers in world history. 
At the same time, it is possible that several even earlier empires in the Near East, for example, the Ancient Egyptian New Kingdom in the time of Pharaoh Akhenaten and the Neo-Assyrian Empire, already had the essential characteristics of an early totalitarian state.

\section{NOTES}

1 The current article has been supported by grant 5374 of the Estonian Science Foundation.

${ }^{2}$ Chinese names in the article have been given in the pinyin transliteration.

312 bronze statutes were made, each weighing 29,960 kilogrammes.

4 Due to repeated attempts on his life, Qin Shi Huangdi was extremely concerned about his life. He even sent out a sea expedition in search of the elixir of immortality for himself (Sima Qian 1975: 71-74).

5 The tomb of Qin Shi Huangdi was built by 700,000 criminals and slaves. All his concubines, many slaves and eunuchs, as well as master builders and architects, were buried with him (Sima Qian 1975: 87).

6 Traditional Chinese unit of distance, approx. $500 \mathrm{~m}$.

\section{REFERENCES}

Durrant, Stephen W. 1987. Legalism. In: Mircea Eliade (ed.) The Encyclopedia of Religion, Vol. 16. New York; Macmillan Publishing Company, pp. 497-499.

Kryukov 1972 = Kriukov, Mikhail. Syma Tsian' i ego Shi. [Sima Qian and His Shiji.] In: Sima Qian. Istoricheskie zapiski (Shi tszi). [Historical Notes.] T. 1. Moskva: Nauka, pp. 12-65.

Kryukov et al. 1983 = Kriukov, Mikhail \& Perelomov, Leonard \& Sofronov, Mikhail \& Cheboksarov, Nikolai. Drevnie kitaitsy v epokhu tsentralizovannykh imperii. [Ancient Chinese in the Era of Centralised Empires.] Moskva: Nauka.

Kulmar, Tarmo 2003. Totalitarianism and the Role of Religion in the Inca State. Folklore: Electronic Journal of Folklore, Vol. 23, pp. 25-39. doi:10.7592/FEJF2003.23. incastate.

Perelomov, Leonard 1962. Imperiia Tsin' - pervoe tsentralizovannoe gosudarstvo v Kitae (221-202 do n. e.). [The Empire of Qin as China's First Centralised State.] Moskva: Izdatel'stvo vostochnoi literatury.

Perelomov, Leonard 1981. Konfutsianstvo i legizm v politicheskoi istorii Kitaia. [Confucianism and Legalism in China's Political History.] Moskva: Nauka. 
Shang Yang 1993 = Iang Shang. Shang jun shu: Kniga pravitelia oblasti Shan. [The Book of the Lord of Shang.] Perevod s kitaiskogo, vstupitel'naia stat'ia, kommentarii i posleslovie L. Perelomova. Moskva: Ladomir.

Sima Qian 1975. Istoricheskie zapiski (Shi tszi). Perevod s kitaiskogo i kommentarii R.V. Viatkina i V.S. Taskina pod obshchei redaktsiei R.V. Viatkina. [Historical Notes. (Shiji).] T. 2. Moskva: Nauka.

Vasilyev 1989 = Vasil'ev, Leonid. Problemy genezisa kitaiskoi mysli. [Problems of the Genesis of Chinese Philosophical Thought.] Moskva: Nauka.

Vyatkin 1972 = Viatkin, Rudol'f. Osnovnye zapisi kak istoricheskii istochnik. [Basic Annals as a Historical Source.] In: Sima Qian. Istoricheskie zapiski (Shi tszi). [Historical Notes. (Shiji).] T. 1. Moskva: Nauka, pp. 66-130. 